\title{
First year seed softening in three Hedysarum spp. in southern Queensland
}

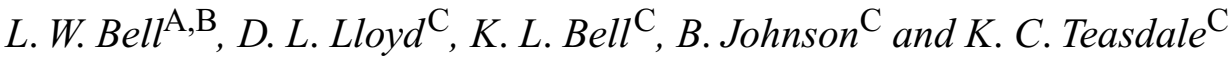

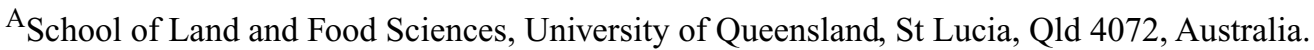 \\ ${ }^{B}$ Present address: School of Plant Biology, University of Western Australia, Nedlands, WA 6009, Australia; \\ author for correspondence; e-mail: lbell@agric.uwa.edu.au \\ ${ }^{\mathrm{C}}$ Department of Primary Industries Queensland, PO Box 102, Toowoomba, Qld 4350, Australia.
}

\begin{abstract}
Seed softening was investigated in 41 lines of Hedysarum coronarium, 5 lines of H. carnosum and 8 lines of H. flexuosum grown at Oakey, Queensland in 2000. After testing for initial hard seed content in each line, the remaining hard seeds were placed on the soil surface at Kingsthorpe on 15 January 2001. Changes in hard seed levels over the ensuing summer-autumn seed softening period were measured. The initial hard seed content in each species ranged from 20 to $79 \%$ in H. coronarium; 31 to $79 \%$ in $H$. carnosum; and 54 to $83 \%$ in H. flexuosum. No significant difference in the time of seed softening between accessions or species was identified. Despite the similar timing, the extent of softening varied greatly between accessions and species. The proportion of initially hard seed that softened ranged from 54 to $95 \%$ in H. coronarium; 27 to $45 \%$ in H. carnosum; and 50 to $74 \%$ in H. flexuosum. Accessions of H. coronarium and H. flexuosum softened the greatest proportion of seed between 15 January and 22 February with reducing amounts thereafter. Accessions of $H$. carnosum softened less seed over this period, appearing to display a slower, more constant rate of softening. Although total hard seed levels were relatively low, there was sufficient variability in hard seed levels to provide some scope for selection of desired hard seed characteristics.
\end{abstract}

Additional keywords: hard seed, Sulla, forage legume, genotypic variation.

\section{Introduction}

The genus Hedysarum is native to temperate Europe and the Mediterranean basin (Woodgate et al. 1999), an area that has provided a large number of commercially useful forage legumes for southern, western and subtropical Australia. It contains 3 species with apparent potential for Australian agriculture. Hedysarum coronarium L. (Sulla) is an important forage species that is used in southern Europe, North America and New Zealand for fodder and hay production (Whyte et al. 1953). Other species with forage potential include $H$. carnosum Desf. and H. flexuosum L. The genus contains species with varying phenology, ranging from short-lived perennials, $H$. coronarium and H. carnosum, to the annual $H$. flexuosum (S. J. Hughes pers. comm.). The perennial nature of $H$. coronarium and $H$. carnosum affords a possible role for these species in areas affected by dryland salinity, through reduction of groundwater recharge. Hedysarum spp. may also play a role to complement lucerne (Medicago sativa $\mathrm{L}$.) for forage and hay production in phases or permanent pasture systems.

Hedysarum coronarium possesses many valuable characteristics for a forage species. It has an ability to produce large quantities of dry matter (DM). Yields of up to $26 \mathrm{t} / \mathrm{ha}$ in the second year have been measured in Australia by de Koning et al. (2003). Hedysarum coronarium fodder is of high quality containing $30 \mathrm{~g} \mathrm{~N} / \mathrm{kg} \mathrm{DM}$ and dry matter digestibility of up to $70 \%$ (Stienezen et al. 1996). The forage contains moderate levels of condensed tannins, which are thought to prevent bloat and possess anti-helminthic properties (Molan et al. 2002). Condensed tannins in ruminant diets have the added benefit of protecting protein against degradation in the rumen thereby increasing amino acid absorption, but when at high levels can lower fodder digestibility and palatability (Stienezen et al. 1996). Hedysarum coronarium is suited to making hay as the leaves remain attached to the stems when dry (Whyte et al. 1953). It is best grown on deep, rich calcareous soils but will perform on poorer soils provided they are not strongly acidic, saline or waterlogged (Whyte et al. 1953). These qualities, and performance in plant nurseries in 1998 throughout Australia, have stimulated interest from researchers and primary producers and have promoted extensive evaluation of this species.

In legumes, impermeability of the seed coat (hardseededness) is the main seed dormancy mechanism. The hard seed mechanism enables seed to survive adverse conditions and to germinate at a time when environmental conditions are suitable for the maintenance of seedling growth and subsequent plant development (Quinlivan 1971). The process of softening of hard seed is driven by 
temperature and is a 2-stage process in other legumes such as subterranean clover (Trifolium subterraneum L.) (Taylor 1981) and some annual medics (Medicago spp.) (Taylor $1996 a$ ). The preliminary or preconditioning stage produces latent soft seeds. This stage can be achieved by constant temperatures, with higher temperatures driving this process more rapidly (Taylor 1981). The second (and final) stage of softening occurs when latent soft seeds are subjected to appropriate temperature fluctuations. These are controlled genetically and vary between species and accessions of the same species (Taylor et al. 1984; Taylor 1996b). Therefore, the second stage of softening will only occur when suitable diurnal temperature fluctuations are experienced in the field. The timing of seed softening is of special significance as it affects the ability of seeds to survive 'false breaks'. False breaks occur when early season rainfall induces germination of seedlings which perish without follow up rain. In Mediterranean environments, seeds that soften in summer are susceptible to early germination and unsuccessful establishment. Subterranean clover requires $60 / 15^{\circ} \mathrm{C}$ day/night diurnal temperature fluctuations to germinate, which means both stages of softening will occur simultaneously during summer and leave seeds susceptible to a false break (Taylor 1981). On the other hand some medic genotypes require a diurnal temperature fluctuation of $35 / 10^{\circ} \mathrm{C}$ (Taylor 1996b), which in Mediterranean environments doesn't occur until autumn. The seeds of these genotypes remain impermeable through summer and early autumn and are more likely to survive false breaks (Smith et al. 1996; Taylor 1996a).

Environmental and genetic factors affect the development of hard seeds and their subsequent softening in the field. Seeds produced in shortened growing seasons have been shown to soften more quickly, e.g. subterranean clover (Aitken 1939; Quinlivan 1965; Taylor et al. 1984) and annual medics (Taylor and Ewing 1992, 1996). Genotypic variation in seed softening pattern has also been demonstrated in subterranean clover (Quinlivan 1965, 1966; Quinlivan and Millington 1962; Taylor et al. 1984), annual medics (Taylor 1996b) and yellow serradella (Ornithopus compressus L.) (Revell et al. 1998). However, the effect of genotype is frequently confounded by environmental influences.

The persistence of hard seeds and the timing of their softening are of great importance for annual legumes that rely on the maintenance of a soil seed bank to persist. The development of a persistent seed bank spreads germination over a number of years and acts as a buffer for poor seasons in which little or no seed is produced and during crop phases when tillage and herbicide practices ensure that pasture seeds are not produced (Crawford and Nankivell 1989; Taylor 1985).

Little research has been undertaken on seed softening in perennial legumes. The importance of hard seed and timing of seed softening in perennial plants is of lesser importance than in annuals, as perennials do not rely solely on soil seed reserves to persist. However, for short-lived perennials in permanent pastures or extended pasture phases ( $>3$ years), hard seed and the seed softening pattern are important to promote successful regeneration. In a phase farming system, the need for costly reseeding could be avoided if the soil seed reserve could be maintained over a period of 3 or more years during the cropping phase and therefore enable sufficient seedling establishment to occur in the following season.

The objective of this study was to investigate genotypic variation in hard seed levels and the pattern of softening in Hedysarum coronarium, $H$. carnosum and $H$. flexuosum. This was a component of a project that is part of a national evaluation program for the development of new cultivars of Hedysarum spp.

\section{Materials and methods}

Ninety-four lines of 3 Hedysarum species were sown on 26 June 2000 near Oakey, Queensland $\left(27^{\circ} 24^{\prime} \mathrm{S}, 151^{\circ} 44^{\prime} \mathrm{E}\right)$. The growing season rainfall for 2000 is presented in Table 1. Lines were grown in 2 by $1 \mathrm{~m}$ plots bordered by $1 \mathrm{~m}$ strips of lucerne that was allowed to flower at the same time as the Hedysarum spp. in an attempt to minimise out-crossing between lines. Plots were visited weekly, and the time of first flowering was recorded. Pods were collected by hand from the plants on 7 December 2000. Fifty-four lines were harvested: 41 of H. coronarium, 5 of H. carnosum, and 8 of H.flexuosum. Due to the dry growing season, 40 lines failed to set seed.

Seeds were removed by rubbing pods gently between corrugated rubber mats. To ensure this process did not break the seed coat, a preliminary test was carried out to determine if this rubbing treatment scarified the seed. Subsamples of 50 seeds were taken from 1 line and seeds were removed by hand and by rubbing. No significant difference in the proportion of soft seeds was detected between the 2 methods. Pods were stored in a glasshouse where constant air temperatures were maintained while seeds were being removed.

\section{Initial seed populations}

From the total populations of seed harvested from each line, light and poorly developed fractions were discarded and plump seed was retained for the study. The light fraction was regarded as non-germinable seed, and varied in quantity between lines so was discarded to remove any bias on the determination of hard seed. Retained seeds were placed on moist blotting paper in a germination tray on 8 January 2001 for 3 days at a temperature of $24^{\circ} \mathrm{C}$. The number

Table 1. Monthly rainfall during the 2000 growing season, long-term average rainfall (100 years) and first decile monthly rainfall $(\mathrm{mm})$ at Oakey

\begin{tabular}{lccc}
\hline Month & Rainfall & Long-term rainfall & First decile rainfall \\
\hline May & 17.8 & 47.8 & 5.7 \\
June & 42.0 & 27.4 & 4.4 \\
July & 11.8 & 34.9 & 6.4 \\
August & 4.4 & 25.7 & 0.4 \\
September & 1.0 & 33.0 & 2.0 \\
October & 31.0 & 56.9 & 16.8 \\
November & 57.0 & 79.0 & 16.8 \\
Total & 165.0 & 304.7 & $183.0^{\mathrm{A}}$ \\
\hline
\end{tabular}

${ }^{A}$ Decile 1 rainfall for May to November. 
of soft and hard seeds was counted. The proportion of imbibed soft seed that germinated was not determined. Due to time limitations in this study, counts were not continued beyond 3 days. In these species there is no evidence of a delay in germination of soft seed ( $>3$ days), as was found in yellow serradella (Revell et al. 1998). Subsequent work has demonstrated that all soft seed from various accessions of H. coronarium imbibed within 4 days (K. Foster unpublished data). Initial hard seed percentage was calculated as the ratio of the number of impermeable seeds to the total number of seeds retained for measurement. Remaining hard seed from each line was removed from the germination trays, dried at room temperature (about $24^{\circ} \mathrm{C}$ ) for 2 days and then was used in the field softening stage of the study.

Softened seed and pattern of softening

Seeds that were initially hard were divided into lots of 50 , placed in nylon mesh bags and allocated to 1 of 4 sampling occasions with 2 replicates each. In many lines there was insufficient seed for the full sampling schedule. In these instances the number of replicates was reduced to 1 and if insufficient seed was still available, sampling occasions of lower priority were omitted. The full sampling schedule was carried out for 15 lines of $H$. coronarium, 3 lines of $H$. carnosum and 6 lines of H. flexuosum (identified in Table 2). Bags were placed on the surface of a black earth at Kingsthorpe, Queensland (10 km east of Oakey), on 15 January 2001 and secured with wire stakes. Bags were placed in the field in a random 2 block design. Bags were removed from the field at about 6-week intervals on 22 February, 6 April, 18 May and 26 June 2001 and the remaining seeds were placed on a moist germination tray, as described previously. The number of hard seeds remaining and imbibed (soft) seeds were counted. Any seeds not recovered were counted as soft, as they had germinated in the field. The number of germinated seedlings was not measured. Hard seed levels (as a percentage of seed initially hard) were measured for all lines on 26 June 2001. Percentage of residual hard seed was determined as a product of hard seed level after the softening stage and the percentage of seeds that were initially hard.

A bare soil surface was maintained to ensure soil surface temperatures in the plot did not vary due to vegetative cover. Encroaching vegetation and any germinating seedlings were killed by application of glyphosate. Soil surface temperatures were measured throughout the period of softening using a temperature sensor attached to a multi-channel recorder.

Statistical analyses

Data on the initial percentage of hard seeds were not subjected to statistical analysis as the whole population was tested and only 1 value for each line was obtained. Statistical analysis was complicated by the non-orthogonal nature of the data. The design of the experiment was an unbalanced, incomplete factorial of 54 lines by 4 harvest dates, arranged in 2 blocks. The data were subjected to analysis of variance in Genstat 5 (Genstat 5 Committee 2001). Block effects were not significant and were omitted. Adjusted means of percentage hardseededness were generated for all sampling times for each line tested.

\section{Results}

Initial seed populations

Rainfall at Oakey during the growing season in 2000 was well below average (Table 1) and in the lowest decile of rainfall recorded for this period. Plant establishment was successful and there was good vegetative growth after rain in June. Subsequent rainfall was below average and severe water stress affected the plants during their reproductive stage. Many lines grown failed to set sufficient mature pods to be harvested and many pods did not contain mature seed.
Average seed weights ranged from 0.9 to $3.3 \mathrm{mg}$ in H. coronarium, 1.2 to $3.0 \mathrm{mg}$ in H. carnosum and 2.0 to $3.7 \mathrm{mg}$ in $H$. flexuosum. Lines of $H$. carnosum flowered before those of $H$. coronarium [77-98 days to flowering (DTF) compared with 98-128 DTF] and H. flexuosum (109-128 DTF). The initial germination test found that percentage hard seed at seed maturity varied within each of the 3 species (Table 2) with the following ranges of initial percentage hard seed measured: $H$. coronarium, 19.6-79.2\%; H. carnosum, 30.7-79.3\%; and H. flexuosum, $54.1-83.2 \%$. Lines with the highest percentage hard seed initially were: $H$. coronarium, HS26, HS29, HS31, HS32, HS74; H. carnosum, HC02, HF01; and H. flexuosum, HF09, all with $>75 \%$ hard seed. Average seed weight was shown to be related to the percentage of seed initially hard (Fig. 1) with lines that produced smaller seeds having lower initial hardseededness. However, there was no relationship between flowering time and seed size or percentage of seed initially hard.

\section{Softened seed}

Diurnal temperature fluctuations recorded at the (bare) soil surface of a nearby site for the period of sampling are presented in Figure 2. Minimum soil surface temperatures were low from mid-May until July, reflecting the occurrence of frequent frosts. Compared with Mediterranean climates (Taylor 1996a; Revell et al. 1998), maximum summer soil surface temperatures were variable and not particularly high, a result of cloudy conditions and rainfall during this period.

The proportion of seed initially hard that softened varied greatly within species (Table 2). Values ranged from 54.0\% (HS57) to $95.4 \%$ (HS51) in H. coronarium, 26.8\% (HC02) to $45.0 \%$ (HC01) in H. carnosum, and $50.2 \%$ (HF01) to $73.6 \%$ (HF03) in H. flexuosum. The proportion of all seeds that remained hard after the first year (residual hard seed) was low in all species with mean percentages of 35.4, 27.4 and 15.7 for $H$. carnosum, $H$. flexuosum and $H$. coronarium, respectively. Hedysarum carnosum $\mathrm{HC} 02$ displayed the highest level of residual hard seed of all lines with $58.1 \%$ of all seeds remaining hard. Hardest lines in H. coronarium and H. flexuosum were HC57 and HF01, where 32.4 and 39.8\%, respectively, of seed remained impermeable.

\section{Seed softening pattern}

Significant differences in the time of softening were not identified between species or accessions. The mean hard seed percentage throughout the softening period for each species (determined from lines that underwent the full sampling schedule) is shown in Figure 3. Despite the similar pattern of softening, differences in the extent of softening between 15 January and 22 February were obvious between species. In $H$. coronarium and $H$. flexuosum a large proportion of seed softened over this period, while in $H$. carnosum much less seed softened. In all species little seed softened after 
Table 2. Origin, days to flowering, original seed populations, seed softened and residual hard seed levels for all lines tested

\begin{tabular}{|c|c|c|c|c|c|c|}
\hline Accession & Origin $^{\mathrm{A}}$ & $\begin{array}{l}\text { No. of days } \\
\text { to flowering }\end{array}$ & $\begin{array}{l}\text { Mean seed } \\
\text { mass (mg) }\end{array}$ & $\begin{array}{l}\text { Initial hard } \\
\text { seeds }(\%)^{B}\end{array}$ & $\begin{array}{l}\text { Residual hard } \\
\text { seeds }(\%)^{\mathrm{B}}\end{array}$ & $\begin{array}{c}\text { Seed softened } \\
(\%)^{\mathrm{C}}\end{array}$ \\
\hline \multicolumn{7}{|c|}{ Hedysarum coronarium } \\
\hline HS04 & Sicily & 109 & 2.5 & 62.2 & 24.6 & 60.5 \\
\hline $\mathrm{HS}_{09}{ }^{\mathrm{D}}$ & Sicily & 109 & 2.6 & 73.5 & 22.2 & 69.8 \\
\hline HS10 & Sicily & 101 & 2.1 & 63.4 & 14.9 & 76.6 \\
\hline $\mathrm{HS} 11^{\mathrm{D}}$ & Sicily & 113 & 1.5 & 48.9 & 10.5 & 78.6 \\
\hline HS12 & Bulgaria & 113 & 1.8 & 48.3 & 5.7 & 88.3 \\
\hline $\mathrm{HS} 13^{\mathrm{D}}$ & Bulgaria & 111 & 2.1 & 63.3 & 12.3 & 80.6 \\
\hline HS14 & Spain & 113 & 2.6 & 65.5 & 15.6 & 76.2 \\
\hline $\mathrm{HS} 19^{\mathrm{D}}$ & Morocco & 109 & 1.9 & 56.8 & 7.5 & 86.8 \\
\hline HS21 & Tunisia & 113 & 2.0 & 58.8 & 10.4 & 82.3 \\
\hline HS22 & Tunisia & 101 & 0.9 & 19.6 & 1.1 & 94.5 \\
\hline $\mathrm{HS} 26^{\mathrm{D}}$ & Tunisia & 98 & 2.4 & 75.0 & 29.0 & 61.3 \\
\hline $\mathrm{HS} 27^{\mathrm{D}}$ & Tunisia & 109 & 1.6 & 65.5 & 21.7 & 66.9 \\
\hline HS28 & Australia & 113 & 3.2 & 68.4 & 3.3 & 95.2 \\
\hline $\mathrm{HS} 29^{\mathrm{D}}$ & Italy & 109 & 2.4 & 76.1 & 27.7 & 63.5 \\
\hline HS31 & Tunisia & 128 & 3.1 & 75.5 & 11.4 & 84.9 \\
\hline $\mathrm{HS} 32^{\mathrm{D}}$ & Sicily & 98 & 3.0 & 79.2 & 21.0 & 73.5 \\
\hline $\mathrm{HS} 33^{\mathrm{D}}$ & Tunisia & 98 & 2.7 & 70.8 & 28.2 & 60.3 \\
\hline $\mathrm{HS} 34^{\mathrm{D}}$ & Tunisia & 98 & 2.2 & 73.9 & 29.0 & 60.8 \\
\hline HS43 & Spain & 109 & 1.4 & 45.5 & 12.1 & 73.5 \\
\hline HS47 & Sicily & 116 & 2.1 & 63.1 & 14.6 & 76.8 \\
\hline HS51 & Sicily & 122 & 2.2 & 51.6 & 2.4 & 95.4 \\
\hline HS53 & Sicily & 109 & 1.5 & 45.0 & 11.2 & 75.2 \\
\hline $\mathrm{HS} 54^{\mathrm{D}}$ & Sicily & 101 & 2.1 & 60.0 & 19.5 & 67.5 \\
\hline HS56 & Sicily & 109 & 1.8 & 56.7 & 19.1 & 66.3 \\
\hline HS57 & Sicily & 98 & 2.2 & 70.4 & 32.4 & 54.0 \\
\hline HS58 & Sicily & 109 & 2.3 & 65.3 & 13.1 & 80.0 \\
\hline HS59 & Sicily & 109 & 2.1 & 71.4 & 11.4 & 84.1 \\
\hline HS60 & Sicily & 109 & 2.4 & 72.1 & 15.2 & 78.9 \\
\hline HS61 & Sicily & 109 & 1.8 & 66.4 & 8.4 & 87.4 \\
\hline HS66 & Sicily & 109 & 2.5 & 61.6 & 17.4 & 71.8 \\
\hline $\mathrm{HS} 67^{\mathrm{D}}$ & Sicily & 101 & 2.7 & 74.6 & 26.5 & 64.4 \\
\hline HS70 & USA & 113 & 1.5 & 44.3 & 3.5 & 92.0 \\
\hline $\mathrm{HS} 71^{\mathrm{D}}$ & Tunisia & 113 & 2.8 & 68.4 & 10.4 & 84.8 \\
\hline HS72 & Tunisia & 109 & 1.4 & 46.0 & 18.7 & 59.4 \\
\hline $\mathrm{HS} 3^{\mathrm{D}}$ & Tunisia & 109 & 3.0 & 74.4 & 30.3 & 59.3 \\
\hline HS74 & Tunisia & 109 & 3.3 & 77.0 & 20.9 & 72.8 \\
\hline $\mathrm{HS} 75^{\mathrm{D}}$ & Tunisia & 113 & 1.6 & 67.2 & 21.7 & 67.7 \\
\hline HS76 & Tunisia & 113 & 2.1 & 57.5 & 9.0 & 84.3 \\
\hline HS77 & Tunisia & 109 & 1.2 & 40.0 & 5.3 & 86.7 \\
\hline HS79 & Tunisia & 109 & 2.3 & 70.2 & 18.1 & 74.2 \\
\hline HS81 & Unknown & 122 & 1.5 & 53.1 & 5.6 & 89.5 \\
\hline Mean & & & 2.2 & 62.1 & 15.7 & 75.8 \\
\hline s.e. & & & 0.1 & 2.0 & 1.3 & 4.0 \\
\hline \multicolumn{7}{|c|}{ Hedysarum carnosum } \\
\hline $\mathrm{HC} 01$ & Tunisia & 77 & 1.7 & 43.8 & 24.1 & 45.0 \\
\hline $\mathrm{HCO} 2$ & Tunisia & 77 & 3.0 & 79.3 & 58.1 & 26.8 \\
\hline $\mathrm{HCO}^{\mathrm{D}}$ & Tunisia & 77 & 1.2 & 30.7 & 20.1 & 34.7 \\
\hline $\mathrm{HC} 04^{\mathrm{D}}$ & Tunisia & 77 & 2.1 & 53.2 & 35.6 & 33.1 \\
\hline $\mathrm{HC} 05^{\mathrm{D}}$ & Tunisia & 98 & 1.9 & 56.2 & 39.2 & 30.3 \\
\hline Mean & & & 2.0 & 52.6 & 35.4 & 34.0 \\
\hline s.e. & & & 0.3 & 8.0 & 6.7 & 2.4 \\
\hline \multicolumn{7}{|c|}{ Hedysarum flexuosum } \\
\hline $\mathrm{HF} 01^{\mathrm{D}}$ & Unknown & 113 & 3.7 & 79.9 & 39.8 & 50.2 \\
\hline HF03 & Bulgaria & 116 & 3.3 & 63.2 & 16.7 & 73.6 \\
\hline
\end{tabular}


Table 2. Continued

\begin{tabular}{lcccccc}
\hline Accession & Origin & $\begin{array}{c}\text { No. of days } \\
\text { to flowering }\end{array}$ & $\begin{array}{c}\text { Mean seed } \\
\text { mass }(\mathrm{mg})\end{array}$ & $\begin{array}{c}\text { Initial hard } \\
\text { seeds (\%) }\end{array}$ & $\begin{array}{c}\text { Residual hard } \\
\text { seeds (\%) }\end{array}$ & $\begin{array}{c}\text { Seed softened } \\
(\%)^{\mathrm{C}}\end{array}$ \\
\hline HF04 $^{\mathrm{D}}$ & Morocco & 113 & 2.0 & 54.7 & 19.6 & 64.3 \\
HF05 $^{\mathrm{D}}$ & Morocco & 113 & 2.4 & 67.0 & 23.4 & 65.0 \\
HF06 $^{\mathrm{D}}$ & Morocco & 113 & 2.1 & 67.9 & 29.6 & 56.4 \\
HF08 $^{\mathrm{D}}$ & Morocco & 116 & 2.7 & 68.2 & 34.8 & 49.0 \\
HF09 $^{\mathrm{D}}$ & Morocco & 109 & 3.3 & 83.2 & 37.6 & 54.8 \\
HF10 & Morocco & 116 & 2.2 & 54.1 & 17.7 & 67.3 \\
Mean & & & 2.7 & 67.3 & 27.4 & 60.1 \\
s.e. & & & 0.2 & 3.7 & 3.3 & 3.1 \\
\hline
\end{tabular}

${ }_{\mathrm{A}}^{\mathrm{L}}$ ittle further information was available on accessions tested. ${ }^{\mathrm{B}}$ The percentage of seed set is based on adjusted accession means.

${ }^{C}$ Percentage of seed initially hard that softened. ${ }^{\mathrm{D}}$ Lines subjected to full sampling schedule.

8 April. Soil surface temperatures recorded before April were higher than later ones, thus suggesting that softening in these species occurs during periods of day/night diurnal temperatures of $50 / 20^{\circ} \mathrm{C}$.

\section{Discussion}

\section{Initial seed populations}

Initial levels of hardseededness observed in all lines in this study were lower than those measured in annual medics (Taylor 1996a, 1996b; Lloyd et al. 1997) and yellow serradella (Revell et al. 1998, 1999) in a range of environments. However, low initial levels of hard seed have been documented in some lines of subterranean clover (Quinlivan and Millington 1962; Quinlivan 1965). While light and deformed seed was discarded following harvest, seed viability was not considered when determining initial hard seed levels in this study. Given the dry growing season the viability of seeds may well have been affected. It is possible that a proportion of non-viable seeds may have been counted in the soft seed fraction in the initial hard seed test. Therefore, initial levels of hardseededness may have been

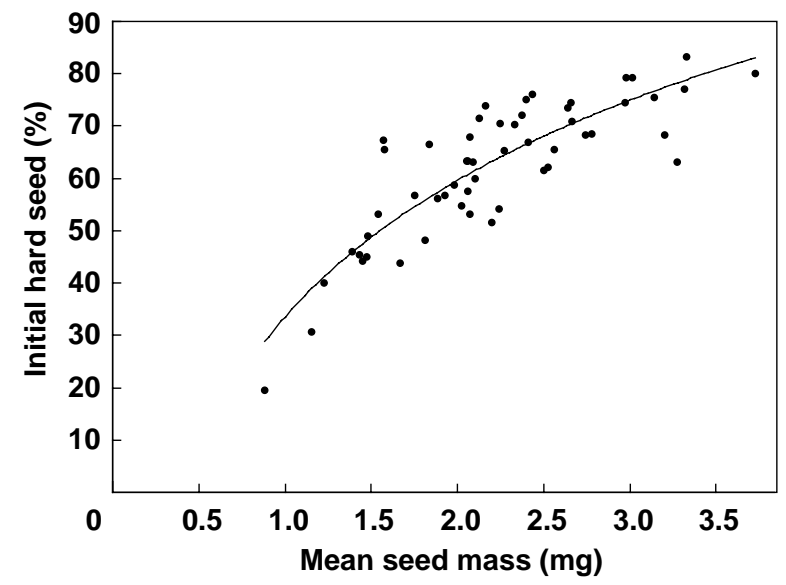

Figure 1. Relationship between mean seed weight $(\mathrm{mg})$ and seed initially hard (\%) in lines of Hedysarum spp. The logarithmic function $y=37.742 \log _{\mathrm{e}} x+33.46\left(r^{2}=0.7405\right)$ best describes this relationship. underestimated to some extent in this study but still provide useful information on this character in Hedysarum spp.

Seed weight was lower for all lines than previously measured in characterisation studies at the Australian Medicago Genetic Resource Centre (S. J. Hughes unpublished data), probably due to plant stress during seed development. Lines with smaller average seed weight were softer at seed set. This contrasts with the finding that smaller seeds in annual medics are harder if their development is not limited (McComb and Andrews 1974). Inhibited seed development in lines with low seed size has probably impacted on seed coat development resulting in a high proportion of soft seeds. The proportion of non-viable seeds in these lines was not measured and may have also contributed to low initial hard seed levels as discussed earlier.

Dry conditions during seed set in this study probably reduced the initial levels of hard seed independent of the possible effects on seed viability. Subterranean clover seed with a longer developmental period has been shown to contain a higher percentage of hard seed at maturity (Aitken

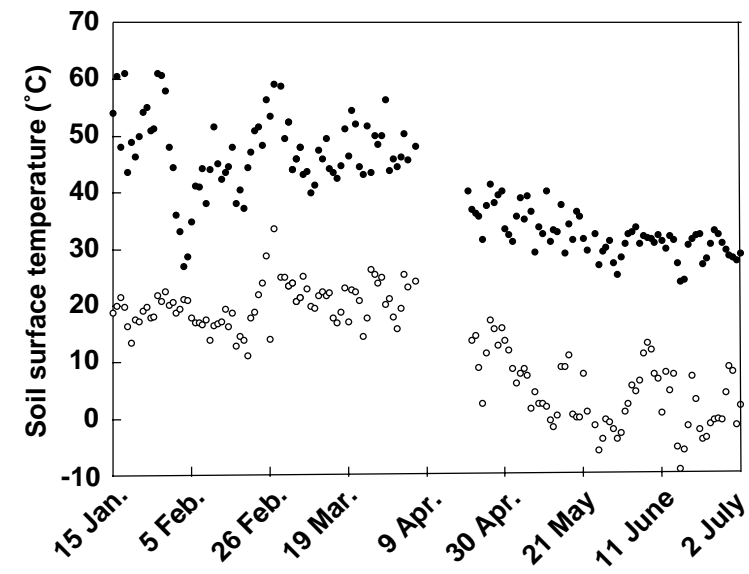

Figure 2. Daily maximum $(\bullet)$ and minimum $(\bigcirc)$ soil surface temperatures recorded from 15 January 2001 to 2 July 2001 at Wellcamp (10 km from Kingsthorpe and same soil type). 
1939; Quinlivan 1965). Early flowering strains of subterranean clover (Aitken 1939; Gladstones 1967; Quinlivan and Millington 1962) and Stylosanthes humilis (Cameron 1967) have higher proportions of initial hardseededness due to their ability to avoid moisture stress during seed formation. There was no relationship between flowering time and seed size or percentage of initial hardseededness in this study. In the 2000 growing season early flowering lines did not necessarily better avoid moisture stress due to rain in October that may have lessened moisture stress on late flowering lines. As in other studies of hard seed dynamics, seasonal environmental factors will affect hard seed values and confound genotypic differences in hardseededness.

\section{Softened seed}

Hedysarum coronarium and H.flexuosum displayed a greater degree of softening in the field in the first year after seed set than has been observed in annual medics (Taylor 1996a, 1996b; Lloyd et al. 1997) and yellow serradella (Revell et al. 1998), with 46.0 and $49.8 \%$ of seed initially impermeable remaining hard in the hardest lines of each species, HS57 and HF01, respectively. However, similar results (high degree of softening) have been obtained for subterranean clover (Quinlivan and Millington 1962). While this may be a characteristic of these genotypes, 2 other factors may have accelerated softening in this case. First, the dry growing season during seed production may have reduced the resistance of seeds to softening. Taylor (1996a) found that growing season environments were more important than seed softening environments in determining rates of softening in all cultivars of burr (Medicago polymorpha L.) and barrel medic (M. truncatula Gaertn.). Medic seeds grown in more favourable environments are usually slower to soften (Taylor and Ewing 1992). Second,

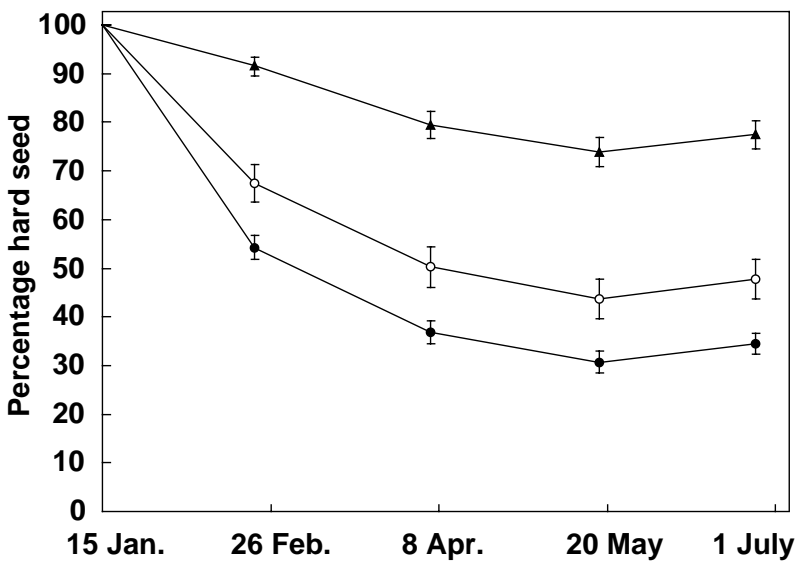

Figure 3. Mean hard seed percentage (of seed initially hard) throughout the summer-autumn softening period for lines of Hedysarum coronarium $(\mathbf{O}), H$. carnosum $(\boldsymbol{\Lambda})$ and H. flexuosum $(\bigcirc)$ subjected to the full sampling schedule (identified in Table 2). Vertical bars indicate standard error of the mean. pods have been shown to insulate seed from high temperatures that soften seeds more rapidly (Barrett-Lennard and Gladstones 1964; Quinlivan 1961, 1966). Hedysarum seed is not readily shed from its pods, either before maturity or after pod drop. Therefore, the artificial removal of seeds from pods in this study may have increased the rate of softening beyond the rate experienced in the field.

The high proportion of hard seed that softened in $H$. coronarium and $H$. flexuosum in this study suggests a poor capacity of these species to develop soil seed reserves for subsequent years in trying seasonal conditions. A failure of germinating seedlings to establish in the year following seed set will result in poor regeneration in subsequent years. In perennial pastures this is less important, providing plants can survive through dry seasons and set seed in following years. But the annual, H. flexuosum, may not persist in variable environments, analogous with the poor persistence of subterranean clover in the more arid mediterranean climates (Bolland 1987; Taylor and Ewing 1992). It is obvious that much less hard seed from the lines of $H$. carnosum tested is softened during the first year than the other 2 species. The proportion of hard seeds that softened in this species was comparable to some medic genotypes in the same environment. This result suggests that $H$. carnosum would maintain a more resistant seed bank than the other 2 Hedysarum species. This result is not unexpected as $H$. carnosum originates from arid environments where plants tend to possess harder-seeded characteristics more suited to variable environments (Ehrman and Cocks 1996).

\section{Seed softening pattern}

Seed softening patterns are of special significance as they predict the ability of seeds to survive germinating rainfall in the absence of follow-up rains (false breaks). In subtropical environments there is no clearly defined optimum time of year for seeds of winter-growing annual pasture plants to soften, as there is in mediterranean climates (Taylor 1996b) and plants can establish at any time between January and July (Lloyd et al. 1997). However, in most years, seed that germinates before March rarely survives and that part of the seed reserve is often wasted. A summer softening pattern, similar to that of barrel medics (Lloyd et al. 1997), is successful in the subtropics because some seed softening and germination can still occur after February, even though seed losses in January and February are likely to be high. Although the majority of softening in $H$. coronarium and H. flexuosum occurred before March, there would still be enough seed to soften and germinate later to enable successful establishment. The slower rate of softening in $H$. carnosum provides soft seed for germination over the whole summer-autumn period and may provide greater protection against false breaks in all environments. However, the lower rates of softening during any one period in 
H. carnosum may reduce the number of seedlings germinating and the sward density unless greater quantities of seed are set. The softening pattern of the Hedysarum species was similar to that shown for barrel medic, which is promising for the suitability of Hedysarum in subtropical environments.

Lower maximum temperatures were observed during summer than those experienced in Mediterranean environments (Taylor 1996b). This was consistent with observations in a previous study on seed softening in medics in a subtropical environment (Lloyd et al. 1997). Since seed softening in the field is driven by daily temperature fluctuations (Quinlivan and Millington 1962) we would expect that this would be responsible for differences in softening patterns between environments. However, Lloyd et al. (1997) found that similar softening behaviours were observed in annual medics in subtropical and Mediterranean environments. Further research is needed to investigate this.

In other studies, seed softening pattern has been shown to differ greatly between genotypes even within the same species, for example between accessions of subterranean clover (Gladstones 1967; Quinlivan and Millington 1962; Smith et al. 1996), burr medic (Taylor 1996b) and yellow serradella (Revell et al. 1998). No significant differences in softening pattern between accessions or species were found. It is likely in the present study the limitations of seed supply for experimental replication and the limited number of lines tested lowered the capacity for differences in seed softening pattern to be determined should they exist.

\section{Practical implications}

The production and preservation of hard seeds is important for the persistence of both annual and perennial legumes in grazed systems. Regeneration of $H$. coronarium in the second year is important to maintain plant numbers and to enhance production (de Koning et al. 2003) and many individual plants of $H$. coronarium only survive for 2 years. Thus, in subsequent years, as older plants are lost, germinating seedlings will be necessary to maintain pasture production. In this study many accessions of $H$. coronarium were found to be particularly soft-seeded. This characteristic, accompanied with the poor seed production observed (data not shown), highlights the need for selection of genotypes that produce more seed with higher hard seed attributes for use in pasture systems. However, in some situations when plant persistence over a number of years is not vital (e.g. short-term pastures or forage crops) soft-seeded lines may be desirable to reduce the need for scarification of seed before sowing. Levels of hard seed in the annual, $H$. flexuosum were low when compared with many other studies on successful annual temperate legumes used in Australia. On the other hand $H$. carnosum has been shown to possess early flowering and higher levels of hardseededness, characteristics of plants better adapted to more arid environments.

It is imperative then that we know something of the hard seed characteristics of Hedysarum to develop successful cultivars. Despite the limitations of this study, significant variation in hard seed levels within each species has been identified, enabling suitable germplasm to be selected in future evaluation programs.

\section{Acknowledgments}

We are grateful for the assistance of Dr H. M. Shelton (School of Land and Food Sciences, University of Queensland) for his co-supervision of L. W. Bell for this project, Scott Wallace and Sue O'Brien for helping gather data during the field experimentation, Steve Hughes (SARDI) for providing seed and information on the lines tested, Graham Taylor, Perry Dolling and the referees for their comments on the paper. Funding for this study was provided by the Grains Research and Development Corporation.

\section{References}

Aitken Y (1939) The problem of hard seeds in subterranean clover. Proceedings of the Royal Society of Victoria 51, 187-212.

Barrett-Lennard RA, Gladstones JS (1964) Dormancy and hardseededness in Western Australian serradella (Ornithopus compressus). Australian Journal of Agricultural Research 15, 895-904.

Bolland MDA (1987) Persistence of seed and a laboratory assessment of seed softening of five subterranean clover cultivars. Journal of the Australian Institute of Agricultural Science 53, 102-105.

Cameron DF (1967) Hardseededness and seed dormancy of Townsville lucerne (Stylosanthes humilis) selections. Australian Journal of Experimental Agriculture and Animal Husbandry 7, 237-240.

Crawford EJ, Nankivell BG (1989) Effect of rotation and cultivation systems on establishment and persistence of annual medics. Australian Journal of Experimental Agriculture 29, 183-188.

de Koning C, Lloyd DL, Hughes SJ, McLachlan D, Crocker G, Bochma S, Craig A (2003) Hedysarum, a new temperate forage legume with great potential - field evaluation. In 'Solutions for a better environment. Proceedings of the 11th Australian agronomy conference'. 2-6 February 2003, Geelong. (Eds M Unkovich, G O'Leary) (The Australian Society of Agronomy: Geelong, Vic.) [CD ROM]

Ehrman T, Cocks PS (1996) Reproductive patterns in annual pasture legume species on an aridity gradient. Vegatatio 122, 47-59.

Genstat 5 Committee (2001) 'Genstat 5 v. 4.21.' (Lawes Agricultural Trust: Rothampstead, UK)

Gladstones JS (1967) Naturalized subterranean clover strains in Western Australia: a preliminary agronomic examination. Australian Journal of Agricultural Research 18, 713-731.

Lloyd DL, Taylor GB, Johnson B, Teasdale KC (1997) Patterns of seed softening and seedling emergence of nineteen annual medics during three years after a single seed crop in southern Queensland. Australian Journal of Experimental Agriculture 37, 767-778.

McComb JA, Andrews R (1974) Sequential softening of hard seeds in burrs of annual medics. Australian Journal of Experimental Agriculture and Animal Husbandry 14, 68-75.

Molan AL, Waghorn GC, McNabb WC (2002) Effect of condensed tannins on egg hatching and larval development of Trichostrongylus colubriformis in vitro. Veterinary Record 150, 65-69. 
Quinlivan BJ (1961) The effect of constant and fluctuating temperatures on the permeability of the hard seeds of some legume species. Australian Journal of Agricultural Research 12, 1009-1022.

Quinlivan BJ (1965) The influence of the growing season and the following dry season on hardseededness of subterranean clover in different environments. Australian Journal of Agricultural Research 16, 277-291.

Quinlivan BJ (1966) The relationship between temperature fluctuations and the softening of hard seeds of some legume species. Australian Journal of Agricultural Research 17, 625-631.

Quinlivan BJ (1971) Seed coat impermeability in legumes. Journal of the Australian Institute of Agricultural Science 37, 283-295.

Quinlivan BJ, Millington AJ (1962) The effect of a Mediterranean summer environment on the permeability of hard seeds of subterranean clover. Australian Journal of Agricultural Research 13, 377-387.

Revell CK, Taylor GB, Cocks PS (1998) Long-term softening of surface and buried hard seeds of yellow serradella grown in a range of environments. Australian Journal of Agricultural Research 49, 673-685.

Revell CK, Taylor GB, Cocks PS (1999) Effect of length of growing season on development of hard seeds in yellow serradella and their subsequent softening at various depths of burial. Australian Journal of Agricultural Research 50, 1211-1223.

Smith FP, Cocks PS, Ewing MA (1996) Short-term patterns of seed softening in Trifolium subterranean, Trifolium glomeratum and Medicago polymorpha. Australian Journal of Agricultural Research 47, 775-785.

Stienezen M, Waghorn GC, Douglas GB (1996) Digestibility and effects of condensed tannins on digestion of sulla (Hedysarum coronarium) when fed to sheep. New Zealand Journal of Agricultural Research 39, 215-221.

Taylor GB (1981) Effect of constant temperature treatments followed by fluctuating temperatures on the softening of hard seeds of Trifolium subterraneum L. Australian Journal of Plant Physiology $\mathbf{8}, 547-558$
Taylor GB (1985) Effect of tillage practices on the fate of hard seeds of subterranean clover. Australian Journal of Experimental Agriculture 25, 568-573.

Taylor GB (1996a) Effect of the environment in which seeds are grown and softened on the incidence of autumn seed softening in two species of annual medics. Australian Journal of Agricultural Research 47, 141-159.

Taylor GB (1996b) Incidence and measurement of autumn seed softening within Medicago polymorpha L. Australian Journal of Agricultural Research 47, 575-586.

Taylor GB, Ewing MA (1992) Long-term patterns of seed softening in some annual pasture legumes in a low rainfall environment. Australian Journal of Experimental Agriculture 32, 331-337.

Taylor GB, Ewing MA (1996) Effects of extended (4-12 years) burial on seed softening in subterranean clover and annual medics. Australian Journal of Experimental Agriculture 36, 145-150.

Taylor GB, Rossiter RC, Palmer MJ (1984) Long term patterns of seed softening and seedling establishment for single seed crops of subterranean clover. Australian Journal of Experimental Agriculture and Animal Husbandry 24, 200-212.

Whyte RO, Trumble HC, Nelson-Leissner G (1953) 'Legumes in agriculture.' (Fernard Agricultural Organisation of the United Nations: Rome, Italy)

Woodgate K, Maxted N, Bennett SJ (1999) A generic conspectus of the forage legumes of the Mediterranean basin. In 'Genetic resources of Mediterranean pasture and forage legumes'. (Eds SJ Bennett, PS Cocks) pp. 194-195. (Kluwer Academic Publishers: London)

Received 4 November 2002, accepted 23 May 2003 